\title{
Editor's Report for Volume 118 (2004)
}

Mailing dates for issues in volume 118 were: (1) 15 December 2004, (2) 10 May 2005, (3), 21 August 2005, (4) 3 March 2006. A summary of membership and subscriber totals 2004 is given in Table 1 . The number of articles and notes in volume 118 is summarized in Table 2 by topic; totals for Book Reviews and New Titles are given in Table 3 , and the distribution of content by page totals per issue in Table 4. 118(1) featured a lead article on the History of The Ottawa Field-Naturalist's Club 1879-2005 prepared by Daniel F. Brunton at the request of council as part the recognition of 125 years of the Club's existence. I am particular indebted to Frank Pope and the Publication Committee: Ron Bedford, Bill Cody, Fenja Brodo, Karen Hamilton, Elizabeth Morton, and Joyce Reddoch; for advice, assistance in choice of illustrations, and review of this paper. Joyce Reddoch (Trail \& Landscape files) and Robert Lee (Macoun Field Club archives) made particularly major contributions to the photo selections. Tributes in volume 118 were to Loris Shano Russell (1904-1998), Thomas Henry Manning (1911-1998) and Victor Kent Prest (1913-2003).

Council continued to contribute $40 \%$ of membership dues for publication. All of subscriptions (both individual and institutional) also go toward publication. Council also has allocated $80 \%$ of the annual interest from the Manning Fund and other capital funds to The Canadian Field-Naturalist. Manning fund portion is specifically to offset the publication cost of northern papers where author and institutional contributions were insufficient to cover page charges.

The journal was printed at Gilmore Printers, Ottawa, and thanks are due business representatives Emil Holst for 118(1) and initiating 118(2), and to Tom Smith for the remaining issues; to customer representatives Ally Reckzin and Chuck Graham for overseeing production and to Wendy Cotie for type inputting, formatting, and corrections for all issues. Particular tribute is due Emil
TABLE 2. Number of articles and notes published in The Canadian Field-Naturalist Volume 118 (2004) by major field of study.

\begin{tabular}{lrcr}
\hline \hline Subject & Articles & Notes & Total \\
\hline 125 Aniversary & 1 & 0 & 1 \\
Mammals & 21 & 12 & 33 \\
Birds & 9 & 9 & 18 \\
Amphibians + reptiles & 2 & 3 & 5 \\
Fish & 3 & 0 & 3 \\
Invertebrates & 5 & 2 & 7 \\
Plants** & 12 & 3 & 15 \\
Multigroups & $2 *$ & 0 & 2 \\
Tributes & 3 & 0 & 3 \\
\hline Totals & 58 & 29 & 87 \\
\hline \hline
\end{tabular}

* includes articles on evironmental change in Nova Scotia and introduced marine species in Haida Gwaii region in 118(1).

Holst who was guardian and guide for Bill and I, and for my predecessor, Loraine Smith (CFN Editor 19721981) since the mid-1970s starting with volume 90 through associations with MOM (formally Mail-OMatic), St. Joseph, and Gilmore printers.

Leslie Cody prepared the Index for volume 118; Elizabeth Morton proofed the galleys. Business Manager Bill Cody handled all liason with the printer and all journal business, including reprint requests and billing and oversaw and proofed the compilation of the Index. Roy John arranged for book reviews, edited them, and prepared the New Titles listing.

Manuscripts (excluding book reviews, notices, and reports) submitted to The Canadian Field-Naturalist totalled 75 in 2004, down 9 from 84 in 2003. The following reviewed for papers submitted in 2004 (with number of manuscripts reviewed in parentheses if more than one): Associate Editors: R. Anderson, Canadian Museum of Nature, Ottawa, Ontario (3); C. D. Bird, Erskine, Alberta (11); R. R. Campbell, St. Albert, Ontario; P. M. Catling, Agriculture and Agri-food Canada,

TABLE 1. The 2004 circulation of The Canadian Field-Naturalist (2003 in parenthesis). Membership totals from Annual Report of the Ottawa Field-Naturalists' Club, January 2005; subscription totals compiled by W. J. Cody. Forty percent of membership dues and $100 \%$ of subscriptions go to publication of The Canadian Field-Naturalist. Members vote on Club affairs, subscribers and institutions do not.

\begin{tabular}{|c|c|c|c|c|c|c|c|}
\hline \multirow{2}{*}{ Memberships } & \multicolumn{2}{|c|}{ Canada } & USA & \multicolumn{2}{|c|}{ Other } & \multicolumn{2}{|c|}{ Totals } \\
\hline & & & & & & & \\
\hline Family \& individual & 717 & (795) & $26 \quad(36)$ & 6 & (7) & 749 & $(838)$ \\
\hline \multicolumn{8}{|l|}{ Subscriptions } \\
\hline Individuals & 165 & (163) & $63 \quad(60)$ & 5 & (6) & 233 & (229) \\
\hline Institutions & 164 & (157) & $246(241)$ & 30 & (30) & 440 & (428) \\
\hline Totals & 1046 & $(1115)$ & $335(337)$ & 41 & (43) & 1422 & $(1495)$ \\
\hline
\end{tabular}

Note: 18 countries are included under "Other" (outside Canada and United States): Australia, Belgium, Denmark, Finland, France (3: including 1 to St. Pierre \& Miquelon), Germany (3), Iceland, Ireland, Japan (2), Netherlands (2), New Zealand (2), Norway (6), Poland, Russia, Spain (2), Sweden (2), Switzerland, and United Kingdom (10: including Scotland and Northern Ireland). 
TABLE 3. Number of reviews and new titles published in Book Review section of The Canadian Field-Naturalist Volume 118 by topic.

\begin{tabular}{lcc}
\hline \hline & Reviews & New Titles \\
\hline Zoology & 48 & 69 \\
Botany & 17 & 16 \\
Environment & 12 & 35 \\
Miscellaneous & 6 & 2 \\
Young Naturalists & 0 & 4 \\
\hline Totals & 83 & 126 \\
\hline \hline
\end{tabular}

Ottawa, Ontario (7); B. W. Coad, The Canadian Museum of Nature, Ottawa, Ontario (5); A. J. Erskine, Sackville, New Brunswick (21); D. F. McAlpine, New Brunswick Museum, Saint John, New Brunswick (7); D. W. Nagorsen, Mammalia Biological Consulting, Victoria, British Columbia (13); W. O. Pruitt, Jr., University of Manitoba, Winnipeg, Manitoba (18); Others: W. B. Ballard, Texas Tech University, Lubbock, Texas; J. Bart, United States Geological Survey, Boise, Idaho; R. Bedford, Ottawa, Ontario; D. R. Bennett, British Columbia Ministry of Forests, Saanichton; J. R. Bider, Ecomuseum, Ste-Anne-de-Bellevue, Quebec (2); S. Boudrup-Nielsen, Acadia University, Wolfville, Nova Scotia; J. Bowman, Ontario Ministry of Natural Resources, Peterbrough, Ontario; E. L. Bousfield, Ottawa, Ontario; J. D. Brawn, University of Illinois, Champaignn, Illinois; I. Brodo, Canadian Museum of Nature, Ottawa, Ontario; M. Burt, University of New Brunswick, Fredericton; D. J. Buckle, Saskatoon, Saskatchewan; C. M. Buddle, McGill University, Macdonald Campus, Ste. Anne-de-bellevue, Quebec; L. Carbyn, Canadian Wildlife Service, Edmonton, Alberta; W. J. Cody, Canada Agriculture and Agri-food, Ottawa; D. Cone, St. Mary's University, Halifax, Nova Scotia; M. Crête, Québec Société de la faune et des parcs, Québec; K. DeSmet, Manitoba Conservation. Winnipeg; A. W, Diamond, University of New Brunswick; L. Foote, University of Alberta, Edmonton; G. Forbes. University of New Brunswick, Fredericton; C. M. Francis, Canadian Wildlife Service, Ottawa, Ontario; J. Gilhen, Nova Scotia Museum of Natural History, Halifax, Nova Scotia (2); P. Goossen, Canadian Wildlife Service, Edmonton, Alberta; P. T. Gregory, University of Victoria, British Columbia; E. Haber, National Botanical Services, Ottawa, Ontario; P. Hamilton, Canadian Museum of Nature, Ottawa, Ontario; M. B. Hickey, St. Lawrence River Institute of Environmental Studies, Cornwall, Ontario; C. S. Houston, Saskatoon, Saskatchewan; R. James, Sutherland, Ontario (2); J. Kamler, Polish Academy of Sciences, Mammal Research Institute, Bialowieza; R. W. Knapton, Edmonton, Alberta; J. M. Knetter, University of Wisconsin-Madison; D. Langor, Edmonton, Alberta; P. F. Larsen, Bigelow Laboratory for Ocean, West Boothbay Harbor, Maine; S. Larivière, Portage La Prairie, Maanitoba; J. Leafloor, Canadian Wildlife Service, Winnipeg, Manitoba; L. E. Licht, York University, North York, Ontario; R. MacCulloch,
TABLE 4. Number of pages per section published in The Canadian Field-Naturalist Volume 118 (2004) by issue.

\begin{tabular}{lrrrrr}
\hline \hline & $(1)$ & $(2)$ & $(3)$ & $(4)$ & Total \\
\hline Articles & 118 & 105 & 135 & 107 & 465 \\
Notes & 19 & 17 & 17 & 16 & 69 \\
Tributes & 0 & 0 & 14 & 12 & 26 \\
Book Reviews* & 17 & 13 & 19 & 14 & 63 \\
CFN/OFNC Reports ${ }^{* *}$ & 0 & 2 & 8 & 3 & 13 \\
News and Comment & 3 & 2 & 2 & 3 & 10 \\
Index & 0 & 0 & 0 & 28 & 28 \\
Advice to Contributors & 1 & 1 & 1 & 1 & 4 \\
\hline Totals & 158 & 140 & 196 & 184 & 678 \\
\hline \hline
\end{tabular}

*Total pages for book review section include both reviews and new titles listings.

***Includes CFN Editors' report in 118(2), OFNC Annual Business Meeting 118(3) and OFNC Awards 118(4).

Royal Ontario Museum, Toronto, Ontario; G. L. Mackie, University of Guelph, Ontario; C. Machtans, Canadian Wildlife Service, Yellowknife, Northwest Territories; A. Martel, Canadian Museum of Nature, Ottawa, Ontario; D. Mazerolle, University of Saskatchewan, Saskatoon; L. D. Mech, U.S. Geological Survey, The Raptor Center, University of Minnesota, St. Paul (4); J. Metcalfe-Smith, National Water Research Institute. Burlington, Ontario; E. Morton, Masham, Quebec; J. S. Nelson, University of Alberta, Edmonton, Alberta; J.-P. Ouellet, Universite du Quebec a Rimouski, Quebec; G. Parker, Canadian Wildlife Service, Sackville, New Brunswick; K. Poole, Aurora Wildlife Research, Nelson, British Columbia; E. F. Pope, Ottawa; R. Poulin, University of Alberta, Edmonton, Alberta; M. Raine, Calgary, Alberta; R. Reeves, Okapi Wildlife Associates, Hudson, Quebec (2); J. Reddoch, Ottawa, Ontario; T. E. Reimchen, University of British Columbia, Victoria: J.-F. Robitaille, Laurentian University, Sudbury, Ontario; F. W. Schueler, Oxford Station, Ontario; S. G. Sealy, University of Manitoba, Winnipeg, Manitoba; N. Simon, Newfoundland and Labrador Natural Resources, Goose Bay; B. Slough, Whitehorse Yukon Territory; S. Smith, Univerisity of Toronto, Ontario; K. W. Stewart, Winnipeg, Manitoba; J. Theberge, Oliver, British Columbia; I. Thompson, Canadian Forest Service, Sault Ste. Marie, Ontario; A. C. Thoresen, McMinnville, Oregon; S. P. Vander Kloet, Acadia University, Wolfville, Nova Scotia.

I am also indebted to the President of the Ottawa Field-Naturalists' Club Gary McNulty and the Club Council for continuing support of the journal; Chairman Ron Bedford and the Publications Committee of the OFNC for editorial encouragement and support, to the Canadian Museum of Nature for access to its library and the facilities at the Natural Heritage Building, 1740 Pink Road, Gatineau [Aylmer sector], Quebec, and to Joyce for everything else.

FRANCIS R. COOK Editor 